$\begin{array}{ll}\text { Abstracta Iranica } & \begin{array}{l}\text { Abstracta Iranica } \\ \text { Revue bibliographique pour le domaine irano-aryen }\end{array} \\ & \text { Volume } \mathbf{2 7} \mid \mathbf{2 0 0 6} \\ & \text { Comptes rendus des publications de } \mathbf{2 0 0 4}\end{array}$

\title{
PRÉFACE - Abstracta Iranica 27 - 2004
}

Rémy Boucharlat, Poupak Rafii Nejad et Dominique Torabi

\section{(2) OpenEdition}

Journals

Édition électronique

URL : http://journals.openedition.org/abstractairanica/6742

DOI : 10.4000/abstractairanica.6742

ISSN : 1961-960X

Éditeur :

CNRS (UMR 7528 Mondes iraniens et indiens), Éditions de l'IFRI

Édition imprimée

Date de publication : 15 mai 2006

ISSN : 0240-8910

\section{Référence électronique}

Rémy Boucharlat, Poupak Rafii Nejad et Dominique Torabi, « PRÉFACE - Abstracta Iranica 27 -

2004 », Abstracta Iranica [En ligne], Volume 27 | 2006, mis en ligne le 02 janvier 2007, consulté le 25

septembre 2020. URL : http://journals.openedition.org/abstractairanica/6742 ; DOI : https://doi.org/

10.4000/abstractairanica.6742

Ce document a été généré automatiquement le 25 septembre 2020.

Tous droits réservés 


\title{
PRÉFACE - Abstracta Iranica 27 - 2004
}

\author{
Rémy Boucharlat, Poupak Rafii Nejad et Dominique Torabi
}

1 A la parution du numéro 26, nous annoncions la mise en ligne prochaine d'Abstracta Iranica sur le site de revues.org : c'est chose faite depuis décembre 2005. Les numéros 25 et 26 sont consultables en ligne, en attendant, avant la fin de 2006, les numéros 24 et 23 . Quant à ce volume 27 , il est mis en ligne concomitamment à la sortie de la version papier, formule qui sera dorénavant poursuivie.

2 Ce volume contient près de 400 entrées : certaines rubriques ont repris vie, du fait de l'intérêt des publications du domaine et de l'activité des collaborateurs, dont l'équipe se renouvelle. Nous sommes heureux que de jeunes chercheurs viennent nous rejoindre, ce qui témoigne du dynamisme de la recherche dans les différents domaines couverts par la revue.

3 Par ailleurs, la mise en ligne répond à un besoin souvent formulé par les lecteurs : comment retrouver un compte-rendu lorsqu'on ne connaît pas précisément l'année de sa parution? L'indexation systématique des numéros récents offrira ainsi à tous un outil supplémentaire. Toutefois, il s'agit d'un travail qui nécessite le concours des lecteurs spécialistes : vos suggestions et remarques seront les bienvenues, à envoyer à l'adresse suivante : abstractairanica@revues.org.

\section{INDEX}

Thèmes : Avant propos 